\title{
KARAKTERISTIK, PENGETAHUAN DAN SIKAP WPS TERHADAP PENCEGAHAN HIV/AIDS HUBUNGANNYA DENGAN PENCARIAN LAYANAN KESEHATAN DI LEBAK
}

\author{
*Rery Kurniawati Danu Iswanto
}

\begin{abstract}
Abstrak
Pelayanan kesehatan merupakan kebutuhan dasar bagi seluruh masyarakat.Kelompok masyarakat yang tidak cukup mempunyai akses layanan kesehatan adalah wanita pekerja seks.Dari risiko pekerjaannya, kelompok ini sangat rentan terhadap masalah kesehatan reproduksi seperti IMS dan HIV/AIDS.Tujuan penelitian ini adalah menganalis faktor-faktor yang mempengaruhi perilaku WPS dalam pencarian layanan IMS dan HIV Di Lebak.

Jenis penelitian ini adalah deskriptif analitik dengan pendekatan cross sectional. Populasi penelitian adalah WPS di Kabupaten Lebak sejumlah 233 orang, dan sampel diambil 60 orang.Data dianalisis secara univariat, bivariat, dan multivariat.

Hasil penelitian menunjukkan bahwa 65\% WPS mempunyai perilaku yang kurang baik dalam pencarian layanan kesehatan. Sebagian besar WPS yaitu $63.3 \%$ melakukan perilaku mengobati sendiri menggunakan jejamuan dan hanya $23.3 \%$ WPS yang mengakses layanan ke instansi pemerintah yaitu puskesmas. Untuk perilaku pencarian layanan oleh tenaga kesehatan, paling banyak digunakan adalah dokter praktik swasta yaitu $86.7 \%$.Uji bivariat menunjukkan faktor alasan menjadi WPS, pengetahuan tentang pencegahan HIV/AIDS, dansikap terhadap pencegahan HIV/AIDS berhubungan dengan perilaku WPS. Berdasarkan analisis multivariat, variabel yang paling berpengaruh terhadap perilaku WPS adalah pengetahuan tentang pencegahan HIV/AIDS ( $p=0.013$, OR=7.069).

Disarankan bagi KPA dan Dinkes.Kab. Lebak agar bekerjasama melakukan sosialisasi pada semua petugas kesehatan di wilayah kerja Dinas Kesehatan Kabupaten Lebak agar memberikan dukungan dengan cara memberikan layanan yang ramah dan tidak diskriminatif bagi WPS, dan memberikan informasi IMS dan HIV/AIDS secara berkala bagi WPS minimal 3 bulan sekali.
\end{abstract}

Kata kunci: perilaku WPS, pencarian layanan, kesehatan.

\section{*Jurusan Kebidanan Rangkasbitung Poltekkes Banten \\ ** Sudah pernah dipresentasikan melalui poster pada Kongres IBI XV di Jakarta}




\title{
CHARACTERISTICS, KNOWLEDGEAND ATTITUDES OF FSW TOWARDHIVIAIDS PREVENTIONIN CORRELATIONWITHHEALTHSERVICES SEEKING BEHAVIOR IN LEBAK
}

\begin{abstract}
Health care is a basic need for all levels of society. One group of people who do not have enough access to health care is a female sex worker (FSW). Notice at the risk of his job, this group is very vulnerable to reproductive health problems such as STI and HIV/AIDS. The purpose of this study was to determine the factors that influence the behavior of FSW in seeking service of STI and HIV In Rangkasbitung City, Lebak.

The study was a descriptive cross sectional analytic approach. The population was FSW in Lebak as much as 233 people, and a sample is taken based on data in the health office of Lebak is 60 people. Data was analyzed by univariate test, the chi square, and logistic regression.

The results showed that $65 \%$ FSW have poorly in seeking of health services. Most of the FSW as much as $63.3 \%$ undertake behavior to treat their own by using herbals and only $23.3 \%$ FSW access government services specifically puskesmas. For behavior of seeking service by health provider, the most widely used is the private practice doctors as much as $86.7 \%$. Bivariate test results suggest that factors of knowledge, and attitude was related to the behavior of FSW. Based on multivariate analysis, the variables that most affect to the behavior of FSW is knowledge about HIVIAIDS prevention ( $p=0.013, O R=7.069)$.

To improve the behavior of FSW in seeking health services of health, it is recommended for the KPA and Health Office of Lebak cooperate to disseminate for all health providers in the District Health Office of Lebak to provide support by providing a friendly service and non discriminatory for FSW, and provide STI and HIVIAIDS information for FSW regularly for at least 3 months.
\end{abstract}

Keywords: FSW behavior, seeking services, health.

\section{Pendahuluan}

Pelayanan

kesehatan

merupakan kebutuhan dasar bagi seluruh masyarakat.Namun demikian, di negara berkembang pada umumnya implementasi layanan kesehatan sulit terlaksana karena kurangnya sumber daya baik dari pemerintah maupun masyarakat.Selain itu, akses terhadap fasilitas yang memberikan layanan kesehatan juga rendah. Studi terdahulu menemukan bahwa kurangnya akses terhadap layanan kesehatan menjadi faktor penting yang menyebabkan rendahnya kondisi kesehatan masyarakat. ${ }^{1 \text { ) }}$

Kelompok masyarakat yang tidak cukup mempunyai akses terhadap layanan kesehatan adalah wanita pekerja seks.Jika melihat dari risiko pekerjaannya, kelompok ini rentan terhadap masalah kesehatan reproduksi

Jurnal Medikes,Volume I, edisi I, April 2014 
seperti IMS dan HIV/AIDS.Pekerjaan WPS yang sering berganti-ganti pasangan seksual, dan tidak konsisten menggunakan kondom berisiko tertular maupun menularkan IMS dan HIV. Oleh karena itu, pada kelompok ini diperlukan pelayanan kesehatan yang komprehensif dan berkesinambungan. ${ }^{23)}$

Survei Terpadu Biologi dan Perilaku (STBP) 2007 menunjukkan prevalensi HIV pada wanita pekerja seks langsung (WPSL) dan wanita pekerja seks tidak langsung (WPSTL) yang baru memulai pekerjaan seks hampir sama tingginya dengan WPS lama. Fakta ini menunjukkan bahwa WPS terinfeksi sangat cepat setelah mulai menjadi pekerja seks. Setiap enam bulan, sepertiga sampai setengah dari WPSL dan 25\% dari WPSTL adalah pendatang baru di bisnis seks WPS yang terinfeksi IMS seperti klamidia, gonore dan sifilis memiliki risiko lebih besar untuk menularkan maupun tertular HIV. Antara 36\% dari WPSL (di Jawa Timur) dan 60\% (di Jakarta) telah terinfeksi setidaknya salah satu dari ketiga IMS tersebut dan WPSTL yang telah terinfeksi, 29\% (di Jawa Timur) hingga 39\% (di Jakarta). ${ }^{4}$
Sekitar 50\% WPS pernah menggunakan layanan medis (umum atau swasta) ketika gejala IMS muncul.Prevalensi klamidia atau gonore lebih rendah di propinsi dengan proporsi tertinggi WPSL yang menerima layanan periksa di klinik IMS pada satu bulan terakhir.Data tahun 2007 menunjukkan bahwa WPS lebih muda yang baru menjadi pekerja seks cenderung tertular infeksi HIV dengan cepat. Mereka yang baru terinfeksi juga berpotensi besar menularkan virus. ${ }^{4)}$

Estimasi resmi saat ini terdapat 95.000-157.000 WPSL dan 85.000-107.000 WPSTL di Indonesia pada tahun 2006.Pada kelompok, prevalensi HIV tertinggi tercatat di Tanah Papua dan Bali, sementara prevalensi tertinggi untuk kalangan WPSTL tercatat di Batam dan Jakarta. ${ }^{5)}$ Di Banten jumlah WPS mencapai 2.408 orang. Berdasarkan data yang dihimpun dari Komisi Penanggulangan AIDS Daerah (KPAD) Provinsi Banten, angka itu tersebar di 7 daerah yaitu Kabupaten Serang 224 orang, Kota Cilegon 189 orang, Kabupaten Tangerang 1.237 orang, Kota Tangerang 55 orang, Kota Tangsel 470 
orang, dan Kabupaten Lebak 233 orang. Jumlah tersebut belum termasuk Kabupaten Pandeglang karena belum dilakukan pemetaan. ${ }^{6)}$

Kabupaten Lebak mempunyai jumlah WPS terbesar ketiga yaitu sejumlah 233 orang yang tersebar di berbagai wilayah.Keberadaan WPS di Lebak sebagian besar berada di Rangkasbitung sebagai ibukota Kabupaten Lebak. Dengan jarak yang cukup dekat ke ibukota Jakarta dan akses yang mudah menggunakan kereta api menjadikan mobilitas WPS di Rangkasbitung sangat tinggi. Jumlah kasus IMS dan HIV/AIDS pada kelompok ini juga belum diketahui secara pasti. Berdasarkan laporan KPAD, jumlah pengidap HIV/AIDS di Lebak ada 81 orang yang terdiri dari kelompok wanita pekerja seks, waria, gay atau lelaki seks lelaki (LSL), dan lelaki berisiko tinggi (high risk man/HRM). ${ }^{7) 8)}$ Sedangkan untuk kasus IMS, laporan Dinkes Lebak tahun 2011 menunjukkan data bahwa dari 36 Puskesmas di wilayah Kabupaten Lebak hanya 5 puskesmas yang melaporkan kasus IMS sebanyak 13 kasus terdiri dari 8 laki-laki dan 5 perempuan. Dari jumlah tersebut hanya
1 orang yang dilaporkan sebagai WPS. ${ }^{9)}$ Hal tersebut tentu saja tidak menggambarkan keadaan yang sebenarnya.Mengingat fenomena gunung es, dengan angka positif HIV 81 orang maka kemungkinan besar angka IMS jauh lebih tinggi.

Di Kabupaten Lebak sendiri belum ada klinik khusus untuk IMS, RSUD Adjidarmo sebagai rumahsakit rujukan juga belum mempunyai dokter ahli untuk menangani IMS dan HIV. Meskipun demikian, layanan terhadap gangguan awal IMS dapat diperoleh melalui 36 Puskesmas yang ada di wilayah Kabupaten Lebak, ditambah dengan dokter swasta, mantri, dan bidan praktik yang tersebar di setiap kelurahan. Mengingat dari 36 Puskesmas hanya 5 puskesmas yang melaporkan kasus IMS, kemungkinan besar WPS di Kabupaten Lebak belum banyak mengakses layanan kesehatan formal seperti Puskesmas maupun rumahsakit. Beberapa pengobatan yang mungkin dilakukan selain ke tenaga kesehatan antara lain adalah mengobati sendiri dengan obat-obatan tradisional, membeli obat-obatan bebas yang dijual di warung, melakukan vaginal practice seperti doucing/gurah vagina, dll. 
Besarnya risiko penyebaran di Kabupaten Lebak dapat dilihat dari adanya lokasi-lokasi yang dijadikan tempat prostitusi. Berdasarkan keterangan dinas kesehatan, terdapat sedikitnya 6 titik lokasi yang memungkinkan terjadinya penyebaran IMS antara lain stasiun kota, alun-alun, Balong, terminal Mandala, terminal Sampay, Karangtaraje, terminal Malingping, dan Cileuweung. Berdasarkan keterangan dari Dinkes Kab.Lebak dilaporkan 1 orang WPS yang terkena IMS selama tahun 2011.hal tersebut diketahui setelah ada WPS yang memeriksakan dirinya ke Puskesmas dalam kondisi sudah parah. 9)

Resiko penyebaran IMS juga dimungkinkan dari adanya hotel dan penginapan yang sering digunakan sebagai tempat transaksi seksual.Berdasarkan keterangan mucikari setempat, setidaknya terdapat dua hotel yang paling sering digunakan sebagai tempat transaksi seksual.Mengenai penggunaan kondom, keterangan mucikari menyatakan bahwa WPS di lingkungannya tidak konsisten menggunakan kondom. Kondom yang didapat secara gratis dari dinas kesehatan masih banyak tersedia di rumah mucikari.

\section{Metode Penelitian}

Jenis penelitian yang digunakan adalah observasi dengan metode penelitian deskriptif analitik yaitu suatu penelitian yang mencoba menggali bagaimana dan mengapa fenomena itu terjadi. Pendekatan waktu pengambilan data penelitian ini adalah cross sectional yaitu suatu penelitian yang dilakukan dengan menggunakan cara pendekatan, observasi atau pengumpulan data sekaligus pada suatu saat (Point time approach).

Populasi penelitian adalah WPS di Kabupaten Lebak.Berdasarkan data dari KPAD Propinsi Banten (2012) terdapat 233 WPS yang tersebar di wilayah Kabupaten Lebak.Kriteria pemilihan sampel penelitian adalah WPS yang mangkal di wilayah Kota Rangkasbitung Kabupaten Lebak, bersedia menjadi subyek penelitian, dan pernah mengalami gejala IMS. Sampel yang diambil dalam penelitian ini adalah total jumlah WPS yang tercatat di Dinkes Lebak pada tahun 2011 yaitu 60 orang. Jumlahnya tersebar di 6 lokasi yaitu stasiun kota 15 orang, alunalun kota 8 orang, Balong 10 orang, 
terminal Mandala 10 orang, orang.

Cileuweung 10 orang, dan Sampay 7

\section{Hasil DAN PEMBAHASAN}

\section{Perilaku WPS Dalam Pencarian}

\section{Layanan Kesehatan.}

Tabel 1. Perilaku WPS dalam Pencarian Layanan

Kesehatan

\begin{tabular}{llcc}
\hline No & Perilaku WPS & $\mathrm{F}$ & $\%$ \\
\hline 1 & Baik & 21 & 35 \\
\hline 2 & Kurang baik & 39 & 65 \\
\hline & Jumlah & 60 & 100 \\
\hline & Berdasarkan & hasil & penelitian
\end{tabular}

diketahui sebagian besar dari jumlah WPS di Kabupaten Lebak mencari layanan kesehatan bukan ke puskesmas atau ke tenaga kesehatan melainkan melakukan alternatif pengobatan lain seperti mengobati sendiri dengan jejamuan, berobat ke dukun, melakukan

Tabel 2. Distribusi Frekuensi

Pencarian Layanan Kesehatan

\begin{tabular}{|c|c|c|c|c|c|c|c|}
\hline \multirow[t]{2}{*}{ No } & \multirow[t]{2}{*}{ Perilaku } & \multicolumn{2}{|c|}{ Melakukan } & \multicolumn{2}{|c|}{$\begin{array}{c}\text { Tdk } \\
\text { mlakkan }\end{array}$} & \multicolumn{2}{|c|}{ Total } \\
\hline & & $\mathrm{F}$ & $\%$ & $\mathrm{~F}$ & $\%$ & $\mathrm{~F}$ & $\%$ \\
\hline 1 & $\begin{array}{l}\text { Mengobati } \\
\text { sendiri dgn } \\
\text { jejamuan }\end{array}$ & 38 & 63.3 & 22 & $\begin{array}{c}36 . \\
7\end{array}$ & $\begin{array}{l}6 \\
0\end{array}$ & $\begin{array}{c}10 \\
0\end{array}$ \\
\hline 2 & $\begin{array}{ll}\text { Berobat ke } \\
\text { dukun }\end{array}$ & 3 & 5 & 57 & 95 & $\begin{array}{l}6 \\
0 \\
\end{array}$ & $\begin{array}{c}10 \\
0 \\
\end{array}$ \\
\hline 3 & $\begin{array}{l}\text { Melakukan } \\
\text { gurah vagina }\end{array}$ & 2 & 3.3 & 58 & $\begin{array}{c}96 . \\
7\end{array}$ & $\begin{array}{l}6 \\
0 \\
\end{array}$ & $\begin{array}{c}10 \\
0 \\
\end{array}$ \\
\hline 4 & $\begin{array}{l}\text { Membeli obat } \\
\text { di warung }\end{array}$ & 3 & 5 & 57 & 95 & $\begin{array}{l}6 \\
0 \\
\end{array}$ & $\begin{array}{c}10 \\
0 \\
\end{array}$ \\
\hline 5 & $\begin{array}{ll}\begin{array}{l}\text { Berobat ke } \\
\text { dokter }\end{array} & \text { ke } \\
\end{array}$ & 52 & 86.7 & 8 & $\begin{array}{c}13 . \\
3\end{array}$ & $\begin{array}{l}6 \\
0 \\
\end{array}$ & $\begin{array}{c}10 \\
0\end{array}$ \\
\hline 6 & $\begin{array}{l}\text { Berobat ke } \\
\text { mantri }\end{array}$ & 23 & 38.3 & 37 & $\begin{array}{c}61 . \\
7\end{array}$ & $\begin{array}{l}6 \\
0\end{array}$ & $\begin{array}{c}10 \\
0\end{array}$ \\
\hline 7 & Berobat ke & 14 & 23.3 & 46 & 76. & 6 & 10 \\
\hline
\end{tabular}

gurah vagina, dan membeli obat bebas di warung.

Oleh karena itu, melihat pada hasil pengamatan terhadap perilaku WPS diatas bisa terdapat kemungkinan bahwa WPS yang termasuk dalam kategori perilaku kurang baik yaitu yang melakukan pengobatan dengan cara mengobati sendiri menggunakan jejamuan, berobat ke dukun, melakukan gurah vagina, dan membeli obat-obatan bebas yang dijual di warung, mempunyai persepsi bahwa perilakunya tersebut sudah baik. Pada keadaan ini, WPS tersebut tidak akan merasa perlu untuk mencari layanan ke tenaga kesehatan maupun puskesmas.

\begin{tabular}{ccc}
\hline puskesmas & 7 & 0 \\
Hasil & pengamatan & yang \\
menunjukkan & rendahnya WPS & yang \\
memanfaatkan puskesmas & $(23.3 \%)$ & dan \\
tinggi untuk perilaku mengobati sendiri & jejamuan $\quad(63.3 \%)$, \\
dengan $\quad$ persepsi tentang \\
kemungkinan besar merupakan indikasi \\
adanya perbedaan
\end{tabular}


konsep sehat sakit antara WPS dan petugas kesehatan.

Melihat besarnya perilaku WPS yang menggunakan layanan dokter praktik swasta $(86.7 \%)$ dibandingkan dengan layanan kesehatan lain yaitu oleh mantri dan puskesmas, mengindikasikan bahwa pengobatan oleh dokter dirasakan lebih baik dan WPS merasa lebih nyaman berobat ke dokter praktik swasta karena terjaga privasinya. Hal ini sesuai dengan penjelasan WPS yang menjadi responden penelitian bahwa banyak WPS yang berobat ke dokter jika mengalami gangguan di alat kelaminnya dan merasa puas dengan pengobatannya karena cepat sembuh.Sedangkan mengenai keterangan tentang pelayanan di puskesmas, WPS mengatakan bahwa jika berobat ke puskesmas sering dipandang sebelah mata oleh petugas dan/atau petugas laki-laki di puskesmas meminta nomor ponsel pribadi mereka.Hal tersebut membuat WPS tidak nyaman berobat ke puskesmas.

Berdasarkan uji statistik yang dilakukan untuk melihat pengaruhnya secara bersama-sama antara 4 variabel bebas yang mempunyai nilai $p \leq 0.25$ yaitu lama menjadi WPS, alasan menjadi WPS, pengetahuan tentang pencegahan HIV/AIDS, dan sikap terhadap pencegahan HIV/AIDS pengaruhnya terhadap perilaku WPS diperoleh hasil 2 variabel yang berpengaruh yaitu pengetahuan tentang pencegahan HIV/AIDS dengan $p=0.013$ dan nilai OR adalah 7.069, dan sikap terhadappencegahan HIV/AIDS dengan $p=0.040$ dan OR adalah 0.213.

Hasil penelitian ini dapat diartikan bahwa yang paling berpengaruh secara signifikan terhadap perilaku WPS adalah variabel pengetahuan tentang pencegahan HIV/AIDS. Dengan nilai OR=7.069, dapat diartikan bahwa WPS yang mempunyai pengetahuan tinggi tentang pencegahan HIV/AIDS berpeluang 7 kali untuk melakukan perilaku pencarian layanan kesehatan yang baik dibanding WPS yang berpengetahuan rendah, setelah dikontrol oleh variabel sikap terhadap pencegahan HIV/AIDS.

Sejalan dengan teori perilaku yang dikembangkan oleh Green, bahwa pengetahuan termasuk dalam faktor predisposisi yaitu hal-hal yang ada sebelum perilaku terbentuk yang memberikan dasar rasional atau 
motivasi untuk berperilaku.Dalam konteks perilaku pencarian layanan kesehatan pada WPS, pengetahuan tentang pencegahan HIV/AIDS dapat mendasari WPS untuk berperilaku secara rasional sesuai dengan pengetahuan yang dimilikinya.

2. Karakteristik Responden. Tabel 3. Karakteristik Responden

\begin{tabular}{|c|c|c|c|}
\hline No & Karakteristik Responden & $\mathrm{F}$ & $\%$ \\
\hline \multirow[t]{5}{*}{1} & Umur & & \\
\hline & a. Muda & 44 & 73.3 \\
\hline & tahun) & 16 & 26.7 \\
\hline & b. Tua ( $\geq 25$ tahun) & 60 & 100 \\
\hline & Jumlah & & \\
\hline \multirow[t]{5}{*}{2} & Tingkat Pendidikan & & \\
\hline & a. $\mathrm{SD}$ & 28 & 46.7 \\
\hline & b. SMP & 21 & 35 \\
\hline & c. SMU & 11 & 18.3 \\
\hline & Jumlah & 60 & 100 \\
\hline \multirow[t]{4}{*}{3} & Pendapatan & & \\
\hline & a. Rendah & 1 & 1.7 \\
\hline & b. Tinggi & 59 & 98.3 \\
\hline & Jumlah & 60 & 100 \\
\hline \multirow[t]{5}{*}{4} & Alasan Menjadi WPS & & \\
\hline & a. Ekonomi & 27 & 45 \\
\hline & b. Pergaulan & 26 & 43.3 \\
\hline & c. Kasus Seks & 7 & 11.7 \\
\hline & Jumlah & 60 & 100 \\
\hline \multirow[t]{4}{*}{5} & Lama Menjadi WPS & & \\
\hline & a. $\quad$ Baru $(\leq 1$ tahun $)$ & 26 & 43.3 \\
\hline & b. Lama (>1 tahun) & 34 & 56.7 \\
\hline & Jumlah & 60 & 100 \\
\hline
\end{tabular}

Sesuai keterangan mucikari bahwa mayoritas WPS berusia muda karena dalam persaingan bisnis seksual WPS yang berusia muda yang lebih bernilai komersial daripada yang sudah tua.Prosentase tersebut lebih besar jika dibandingkan dengan hasil monitoring
Hasil tersebut sesuai dengan penelitian terdahulu oleh Karim tentang perilaku pencegahan penularan IMS pada WPS, penelitian ini menyatakan bahwa terdapat hubungan yang signifikan antara pengetahuan dengan perilaku WPS dalam pencegahan IMS. ${ }^{31)}$

dan evaluasi oleh KPAD Propinsi Banten yang menyebutkan bahwa diperkirakan usia WPS sebesar 40\% adalah remaja usia 16-20 tahun. ${ }^{3}$

Karakteristik usia muda tersebut jika dilihat dari sudut pandang kesehatan reproduksi mempunyai masalah yang khusus. Pada usia WPS yang tergolong muda dan sudah aktif secara seksual perlu mendapat perhatian pada sistem dan fungsi reproduksinya. Ditambah lagi dengan besarnya risiko bagi WPS untuk tertular maupun menularkan IMS karena sering berganti-ganti pasangan seks.Oleh karena itu, selain pentingnya ada layanan kesehatan bagi mereka, layanan kesehatan reproduksi lainnya yang terlebih dahulu harus diberikan pada WPS adalah komunikasi, informasi dan edukasi mengenai pencegahan dan pengobatan IMS dan HIV/AIDS. 
Hasil uji bivariat menunjukkan WPS dengan kategori tua ( $\geq 25$ tahun) lebih banyak yang berperilaku kurang baik yaitu $56.3 \%$, sedangkan WPS dengan kategori muda ( $<25$ tahun) lebih banyak yang berperilaku baik sebesar 68.2\%. Sedangkan nilai $p=0.392$. dapat diartikan bahwa tidak ada hubungan yang signifikan antara umur dengan perilaku WPS. Hal ini sesuai dengan penelitian oleh Karim bahwa tidak ada hubungan yang signifikan antara umur dengan perilaku WPS. ${ }^{33}$ Meskipun secara statistik tidak berhubungan, akan tetapi umur dapat mempengaruhi cara berfikir dan berperilaku seseorang. Dengan bertambahnya umur seseorang bertambah pula pengalamanpengalaman berkaitan dengan layanan untuk IMS dan HIV/AIDS.

Karakteristik responden yang sebagian besar yaitu $46.7 \%$ adalah tamatan SD menunjukkan rendahnya tingkat pendidikan WPS di Kabupaten Lebak.Berbagai penelitian terdahulu menyebutkan bahwa pada umumnya pendidikan formal WPS adalah rendah.Hal ini merupakan kendala tersendiri dalam pemberian informasiinformasi kesehatan karena penerimaan dan pemahaman mereka terhadap materi juga cenderung rendah.Dalam kaitannya dengan pencegahan dan pengobatan IMS diperlukan metode yang efektif agar pesan-pesan perubahan perilaku dapat diterima dan diterapkan oleh WPS.

Uji bivariat menunjukkan bahwa WPS dengan tingkat pendidikan SD lebih banyak yang berperilaku kurang baik sebesar $67.9 \%$ dan sebesar $32.1 \%$ berperilaku baik. WPS pada tingkat pendidikan SMP, sebesar $61.9 \%$ termasuk dalam kategori perilaku kurang baik dan sebesar $38.1 \%$ berkategori baik. Dan WPS dengan tingkat pendidikan SMU juga lebih banyak yang berperilaku kurang baik sebesar $63.6 \%$ dan sebesar $36.4 \%$ berperilaku baik.Dan dengan nilai $p$ pada analisis bivariat adalah 0.906.dapat diartikan bahwa tidak ada hubungan yang signifikan antara tingkat pendidikan dengan perilaku WPS.

Meskipun secara statistik tidak berhubungan, hasil penelitian menunjukkan bahwa di semua kategori tingkat pendidikan baik SD, SMP, maupun SMU prosentase WPS yang mempunyai perilaku kurang baik masih besar.Hasil ini menunjukkan bahwa tingkat pendidikan formal tidak mempengaruhi perilaku pencarian 
layanan IMS dan HIV/AIDS. Kemungkinan yang menyebabkan hal tersebut adalah karena pada kurikulum pendidikan di tingkat SD, SMP, maupun SMU belum ada informasiinformasi berkaitan dengan kesehatan reproduksi khususnya IMS dan HIV/AIDS sehingga WPS tidak mempunyai bekal informasi dari pendidikan formal.

Selanjutnya alasan menjadi WPS sebagian besar yaitu $45 \%$ adalah karena ekonomi, sebesar $43.3 \%$ karena pergaulan, dan $11.7 \%$ karena kasus seksual. Secara umum tingkat ekonomi masyarakat di Kabupaten Lebak termasuk kategori rendah, meskipun secara geografis jarak dari ibukota negara cenderung dekat akan tetapi Kabupaten Lebak termasuk dalam kategori daerah tertinggal. Hasil penelitian ini sesuai dengan hasil monitoring dan evaluasi oleh KPAD Propinsi Banten yang menyatakan bahwa yang menyebabkan mereka menjadi WPS sebagian besar adalah karena faktor ekonomi. ${ }^{3}$

Hasil uji bivariat menunjukkan WPS dengan kategori alasan pergaulan sebagian besar berperilaku kurang baik yaitu sebanyak $80.8 \%$ dan alasan ekonomi $59.3 \%$ berperilaku kurang baik. Dengan nilai $p=0.026$ dapat diartikan ada hubungan yang signifikan antara alasan menjadi WPS dengan perilaku WPS. Hasil penelitian ini sejalan dengan teori yang menyatakan bahwa faktor ekonomi merupakan salah satu hal yang menjadi pertimbangan seseorang dalam menentukan layanan kesehatan. Sebagaimana dikemukakan Notoatmodjo dalam teori perilaku pencarian pengobatan bahwa berbagai alasan yang menyebabkan seseorang tidak menggunakan fasilitas kesehatan adalah jaraknya jauh, takut pergi ke rumahsakit, khawatir dengan biaya, dan sebagainya. ${ }^{21,22}$

$$
\text { Berdasarkan kategori }
$$
pendapatan, hampir seluruh WPS mempunyai pendapatan yang tinggi yaitu 98.3\%.Selanjutnya, dengan hasil pengamatan yang menunjukkan sebagian besar yaitu $56.7 \%$ WPS termasuk dalam kategori lama menjadi WPS, hal ini mengindikasikan bahwa perolehan pendapatan yang tinggi dari hasil pekerjaannya sebagai WPS membuat mereka tetap mempertahankan pekerjaannya sebagai WPS.Hasil uji bivariat pada variabel pendapatan diperoleh hasil hampir seluruh WPS berpendapatan tinggi dan sebesar $64.4 \%$ perilakunya kurang baik. 
Dari hasil uji chi square diperoleh nilai $p=0.459$, dengan demikian tidak terdapat hubungan yang signifikan antara pendapatan dengan perilaku WPS.

Hasil pengamatan terhadap lama menjadi WPS diketahui yang paling lama menjadi WPS adalah selama 15 tahun.Selama rentang waktu tersebut besar kemungkinan WPS tersebut telah tertular maupun menularkan IMS.Berdasarkan hasil wawancara dengan informan, semua WPS yang menjadi responden menyatakan pernah mengalami gangguan di kemaluan dan tetap melayani pelanggan jika kondisinya dirasa belum parah. Kemudian dengan masih rendahnya konsistensi penggunaan kondom, hal tersebut tentu semakin meningkatkan risiko penularan IMS dan HIV/AIDS di Kabupaten Lebak khususnya dan di daerah lain di Indonesia.

\section{Pengetahuan WPS Tentang}

Pencegahan HIV/AIDS.

Tabel 4. Pengetahuan WPS Tentang Pencegahan HIV/AIDS

\begin{tabular}{cccc}
\hline No & $\begin{array}{c}\text { Pengetahuan ttg } \\
\text { HIV/AIDS }\end{array}$ & $F$ & $\%$ \\
\hline 1 & Rendah & 26 & 43.3 \\
\hline 2 & Tinggi & 34 & 56.7 \\
\hline & Jumlah & 60 & 100
\end{tabular}

Hasil uji bivariat pada variabel lama menjadi WPS diketahui bahwa WPS dengan kategori baru ( $1 \leq$ tahun) sebesar $73.1 \%$ mempunyai perilaku kurang baik, dan WPS dengan kategori lama (>1 tahun) sebesar 58.8\% berperilaku kurang baik. Dengan nilai $p=0.251$, maka tidak ada hubungan yang signifikan antara lama menjadi WPS dengan perilaku WPS. Dalam konteks penelitian ini, dapat diartikan bahwa baik WPS baru maupun WPS lama banyak yang tidak mencari layanan kesehatan ke puskesmas atau tenaga kesehatan.Hal tersebut besar kemungkinan karena mereka belum terpapar dengan informasi-informasi layanan kesehatan yang dapat melayani IMS.Hal lainnya adalah disebabkan mereka enggan mendatangi puskesmas atau pun petugas kesehatan karena malu, takut di diskriminasi, dan lain sebagainya.

Berdasarkan rincian jawaban responden mengenai pengetahuan tentang IMS, diperoleh hasil yaitu sebesar $31.7 \%$ WPS tidak tahu bahwa pada waktu 5-10 tahun setelah terinfeksi HIV seseorang dapat tampak sehat tanpa gejala sakit. Sedangkan 
pengetahuan tentang gejala orang yang menderita HIV sebesar 30\% tidak tahu bahwa diare berkepanjangan lebih dari satu bulan dan batuk lama lebih dari satu bulan sebesar $31.7 \%$ merupakan salah satu gejala HIV.

Selanjutnya berdasarkan rincian jawaban responden, diperoleh hasil yaitu sebesar $46.7 \%$ WPS tidak tahu bahwa untuk mencegah penularan HIV/AIDS adalah dengan menggunakan kondom saat berhubungan seks dengan pelanggan, dan sebesar $53.3 \%$ tidak tahu menggunakan kondom jika berhubungan seks dengan pasangan tetap.Mengingat perilaku WPS yang berganti-ganti pasangan seksual dan rendahnya penggunaan kondom, selama periode HIV/AIDS tanpa gejala besar kemungkinan risiko WPS untuk tertular maupun menularkan IMS dan HIV/AIDS.Oleh karena itu penting untuk melakukan tes IMS dan VCT secara berkala baik dirasakan ada gejala maupun tidak. Hal ini sesuai dengan teori yang menyatakan tentang perlunya kegiatan penapisan untuk IMS asymptomatik bagi semua populasi beresiko secara rutin sedikitnya sekali setiap 3 (tiga) bulan. ${ }^{13}$
Rincian jawaban responden selanjutnya mengenai pengetahuan tentang pengobatan dan pencarian layanan HIV/AIDS, diperoleh hasil yaitu sebesar 35\% WPS tidak tahu bahwa mengobati sendiri dengan minum jamu atau obat-obatan yang biasa dijual di warung/toko obat bukan tindakan tepat jika mengalami gejala infeksi HIV. Dan sebesar $43.3 \%$ tidak tahu bahwa tindakan yang tepat adalah pergi ke puskesmas atau tenaga kesehatan.

Secara teori langkah yang tepat untuk pengobatan IMS adalah pergi ke dokter/tenaga kesehatan. Dokter/tenaga kesehatan akan melakukan tes untuk memastikan IMS yang diderita pasiennya. Obat IMS juga berbeda-beda tergantung jenis IMSnya. Berdasarkan hasil tes laboratorium dokter/petugas kesehatan akan tahu obat paling tepat untuk IMS yang diderita pasien. ${ }^{12) 13 \text { ) }}$ Berdasarkan hasil penelitian ini dirasakan perlunya peningkatan pengetahuan berupa layanan KIE tentang mitos penggunaan obat-obat bebas untuk mencegah atau mengobati IMS. 


\section{Sikap WPS Terhadap}

\section{Pencegahan HIV/AIDS.}

Tabel 5. Sikap WPS terhadap

Pencegahan HIV/AIDS

\begin{tabular}{|l|l|c|c|}
\hline No & Sikap WPS & F & $\%$ \\
\hline 1 & Baik & 31 & 51.7 \\
\hline 2 & Kurang baik & 29 & 48.3 \\
\hline & Jumlah & 60 & 100 \\
\hline
\end{tabular}

Berdasarkan rincian pernyataan yang menunjukkan sikap WPS dapat diketahui sikap yang kurang baik sebesar $63 \%$ adalah pada pernyataan harus mengobati sendiri gangguan kesehatan karena IMS menggunakan obat-obatan tradisional responden yang setuju sebanyak $28 \%$ dan ragu-ragu $35 \%$. Hal ini menunjukkan masih besarnya jumlah WPS yang cenderung melakukan pengobatan sendiri jika mengalami gangguan IMS. Selanjutnya item sikap yang kurang baik juga ditunjukkan sebesar $70 \%$ pada pernyataan untuk tidak harus menggunakan kondom jika berhubungan seksual dengan pasangan tetap sebesar setuju 57\% dan ragu-ragu $13 \%$.

\section{Penelitian}

terdahulu

menunjukkan bahwa ada perbedaan antara hubungan yang bermuatan emosional dengan negosiasi seks yang aman.Ketika mereka berhadapan dengan pelanggan baru, mereka lebih mudah dapat bernegosiasi menggunakan kondom, tetapi ketika pelanggan tersebut telah menjadi pelanggan tetap bahkan menjadi kekasih, maka muatan emosional telah mewarnai hubungan mereka sehingga seringkali mengabaikan penggunaan kondom ketika berhubungan seks. Sikap ini perlu diubah melalui peningkatan pengetahuan dan persepsi yang benar tentang penggunaan kondom, mengingat penggunaan kondom adalah salah satu cara yang paling efektif untuk pencegahan dan pengobatan IMS maupun HIV/AIDS.

Hasil uji bivariat menunjukkan nilai $p=0.025$, dengan demikian diartikan bahwa terdapat hubungan yang signifikan antara sikap dengan perilaku WPS. Hasil penelitian ini sesuai dengan penelitian terdahulu oleh Karim tentang faktor-faktor yang berhubungan dengan perilaku WPS dalam pencegahan IMS. Penelitian ini menyatakan bahwa terdapat hubungan yang signifikan antara sikap dengan perilaku WPS dalam pencegahan IMS. ${ }^{33}$ Hasil tersebut juga sesuai dengan teori Green yang menyatakan bahwa sikap merupakan predisposisi seseorang dalam melakukan suatu perilaku dan kedua faktor tersebut saling 


\begin{abstract}
berhubungan. ${ }^{28}$ Perhatian terhadap sikap WPS tetap sangatlah penting mengingat secara teori sikap yang terbentuk dalam diri seseorang menentukan terhadap dilakukannya suatu perilaku.
\end{abstract}

\title{
Simpulan
}

1. Sebesar $65 \%$ WPS mempunyai perilaku kurang baik, dan sebesar $35 \%$ berperilaku baik.

2. Karakteristik responden berdasarkan hasil penelitian diketahui umur responden sebesar $73.3 \%$ berusia muda yaitu umur kurang dari 25 tahun, tingkat pendidikannya sebagian besar 
46.7\% adalah SD, pendapatan hampir seluruh responden yaitu 98.3\% berpendapatan tinggi. Sedangkan untuk alasan menjadi WPS persentase terbesar karena alasan ekonomi sebesar 45\%. Dan untuk kategori lama menjadi WPS sebesar 56.7\% adalah WPS dengan kategori lama menjadi WPS.

3. Pengetahuan tentang pencegahan HIV/AIDS $43.3 \%$ adalah kategori rendah dan 56.7\% kategori tinggi.

4. Sikap WPS terhadap pencarian layanan kesehatan adalah $48.3 \%$ kurang baik dan 51.7 bersikap baik.

5. Ada hubungan signifikan antara pengetahuan tentang pencegahan HIV/AIDS dan sikap terhadap pencegahan HIV/AIDS dengan perilaku WPS dalam pencarian layanan kesehatan.

6. Tidak ada hubungan antara karakteristik WPS (umur, tingkat pendidikan, pendapatan, dan lama menjadi WPS), dengan perilaku WPS dalam pencarian layanan kesehatan.

7. Variabel yang paling berpengaruh terhadap perilaku WPS dalam pencarian layanan kesehatan adalah pengetahuan tentang pencegahan HIV/AIDS. Probabilitas terjadinya perilaku baik menunjukkan bahwa apabila kedua variabel yang berpengaruh secara bersama-sama dalam kategori pengetahuan tinggi dan sikap yang baik, maka probabilitas untuk terjadinya perilaku WPS dalam pencarian layanan kesehatan yang baik adalah sebesar $46 \%$, dan 54\% dipengaruhi oleh variabel yang lain.

\section{Daftar Pustaka}

Hartono D, Romdiati H, Djohan E. Akses Terhadap Pelayanan Kesehatan Reproduksi: Studi Kasus Di Kabupaten Jayawijaya, Irian Jaya. PPT-LIPI. Jakarta. 1999.

KPAN.Strategi dan Rencana Aksi Nasional Penanggulangan HIV dan AIDS 2010-2014. Jakarta. 2009.

Kementerian Pemberdayaan Perempuan, Hak-hak Reproduksi Perempuan. 2011.

Depkes.Surveilans Terpadu Biologis Perilaku pada Kelompok Berisiko. 2007.

Depkes RI. Statistik Kasus HIV/AIDS di Indonesia.Ditjen PPM \& PLP Depkes RI. 2008.

Pekerja Seks di Banten 2.408 Orang.http://satelitnews.co.id/tag/ kpa/, diakses 20 Agustus 2012. 
Empat Kelompok Masyarakat Diawasi. http://www.radarbanten.com/new version/daerah/lebak/.html diakses 20 Agustus 2012.

Dinkes Prop. Banten. Profil Kesehatan Propinsi Banten tahun 2009.

Dinkes Kabupaten Lebak. Laporan P2M\&PL Tahun 2011.

Depkes RI. Modul pelatihan konselor HIV/AIDS. 2011.

Januraga, Pande, Putu. Wulandari, Luh, Putu. Nopiyani, Ni Made, Sri. Pengembangan Pelayanan Komprehensif Berbasis Primary Health Care bagi Pekerja Seks Perempuan di Bali. (tesis). 2010.

Sumarlan.Niat Wanita Pekerja Seks Gajah Kumpul terhadap Pemanfaatan Klinik Infeksi Menular Seksual di Puskesmas Batangan Kab. Pati, Jawa Tengah.Thesis. Program Studi Magister Promosi Kesehatan, Program Pasca Sarjana, Universitas Diponegoro, Semarang. 2008.

Widodo, E. Praktik WPS dalam pencegahan penyakit IMS dan HIV/AIDS di lokalisasi Koplak, Kabupaten Grobogan.Jurnal Promosi Kesehatan Indonesia Vol.4/No. 2/Agustus 2009.

\section{Informasi}

Dasar

IMS/RTI.http://www.aids-ina.org. (diakses 20 Juni 2012)
Infeksi Menular Seksual. channels.dal.net/gim/aids/ims2.ht $\mathrm{ml}$ (diakses 20 September 2012).

$I M S$

dan HIV/AIDS. Available:http://spiritia.or.id/Stats /Statistik.php. 2011. (diakses 25 April 2012)

Depkes RI. Pedoman Penatalaksanaan Infeksi Menular Seksual. Jakarta. 2004.

Depkes RI.USAID.FHI.Standard Operasional Prosedur: Klinik IMS dan VCT Mobile. Jakarta. 2007.

Depkes RI. Pedoman Pelayanan Konseling dan Testing HIV/AIDS Secara Sukarela (Voluntary Councelling and Testing).Dirjen P2\&PL. Depkes RI. Jakarta. 2006.

Notoatmodjo S. Promosi Kesehatan dan Ilmu Perilaku.PT. Rineka Cipta. Jakarta. 2007.

Notoatmodjo S. Pendidikan dan Perilaku Kesehatan.PT. Rineka Cipta. Jakarta. 2005.

Sarwono S. Sosiologi Kesehatan. Gadjah Mada University Press. Yogyakarta. 1993.

Sarwono S. Sosiologi Kesehatan: Beberapa Konsep Beserta Aplikasinya. Gadjah Mada University Press.Yogyakarta. 1997.

Notoatmodjo S. Ilmu Kesehatan Masyarakat : Prinsip-prinsip Dasar, Rineka Cipta. Jakarta. 1997. 
Emillia O. Promosi Kesehatan Dalam Lingkup Kesehatan Reproduksi., Pustaka Cendekia. Yogyakarta. 2008.

Green LW. Health Promotion Planning An Educational and Environmental Approach. Mayfield Publishing Company. USA. 2000.

Notoatmodjo, Soekidjo.Metodologi Penelitian Kesehatan. Rineka Cipta. Jakarta. 2010.

Suharsaputra, Uhar. Metode Penelitian Kuantitatif, Kualitatif, dan Tindakan. Refika Aditama. 2012.

Dahlan, Muhamad Sopiudin. Statistik Untuk Kedokteran dan Kesehatan. Salemba Medika. Jakarta. 2011.

Sianturi SA, Hubungan Faktor Predisposisi, Pendukung Dan Penguat Dengan Tindakan Penggunaan Kondom Pada Wps Untuk Pencegahan Hiv/Aids Di Kabupaten Serdang Bedagai Tahun 2012, Thesis, Program Studi S2 Ilmu Kesehatan Masyarakat, Fakultas Kesehatan Masyarakat, Universitas Sumatera Utara Medan, 2012.

Karim , Risko. Faktor-Faktor Yang Berhubungan Perilaku Pekerja Seks (WPS) Dalam Pencegahan Penularan Penyakit Menular Seksual (PMS)-HIV/AID di Resosialisasi Argorejo Semarang.Undergraduate Thesis, Diponegoro University. 2006.

Widianto, Gunawan.Faktor-Faktor Yang Berhubungan Dengan Praktik Wanita Pekerja Seks
(Wps) Dalam Vct Ulang Di Lokalisasi Sunan Kuning, Semarang. Thesis. Program Studi Magister Promosi Kesehatan, Program Pasca Sarjana, Universitas Diponegoro, Semarang. 2008. 